Original Paper

\title{
Retrospective Evaluation of Gasohol Promotion Policy in Thailand Using an Input-Output Model
}

\author{
Yue MORIIZUMI ${ }^{\dagger}$ \\ (Received January 15, 2016)
}

\author{
産業連関モデルを用いたタイにおけるガソホール促進政策の事後的な評価 \\ 森泉 由恵
}

The Thai government has taken various political measures to promote the use of gasohol as an alternative to fossil-derived gasoline since 2003. The objective of the present study is to evaluate gasohol promotion policy of Thailand in the past from socio-economic and environmental perspectives. A modified input-output model is used to evaluate effects of an increase in gasohol use on the Thai economy from the three aspects, namely, domestic industry development, GHG emission, and employee income. The model is built on the Thai inputoutput table for the year 2005, by disaggregating the original sectors and adding new sectors related to gasohol production. The principal findings are as follows: first, an increase in gasohol use encourages the development of domestic industries through domestic inter-industrial linkages. Second, it decreases the GHG emission from the whole economy associated with a decrease in the use of gasoline; on the other hand, it should be also noted that the GHG emission caused by the gasohol production is not negligible. Third, the gasohol promotion policy increases employee income in the economy as a whole; more importance is that there is the potential increase in income of the rural households.

\section{Key Words}

Bioethanol, Cassava farming, Sugar cane farming, Greenhouse gas emissions, Employee income

タイ政府は，ガソリンの代替燃料としてのガソホールの利用促進を目的として，2003 年から様々な政策を実施してきた。 本研究の目的は, タイでこれまでに行われたガソホール推進政策について, 社会経済および環境の観点から評価することで ある。ガソホール政策分析用に改良した産業連関モデルを用いて, ガソホールの普及拡大がもたらす影響を，国内歩留まり 率の変化, GHG 排出量の変化, 雇用者所得の変化という3つの視点から評価した。新たなモデルは, タイの 2005 年産 業連関表をべースとし, 既存部門を分割するとともにガソホール生産に関連する部門を新設することで作成した。分析結果 から, 以下の知見が得られた。第一に, ガソホールの利用拡大は, 生産波及効果の国内歩留まり率を高め, 国内産業の発 展に寄与する可能性をもつ。第二に, ガソホールの導入は, ガソリン消費量を削減することにより, 国全体の GHG 排出量 削減に貢献する。一方で，ガソホール製造にともなう GHG 排出量は無視できないほどに大きい点にも留意する必要がある。 第三に, ガソホール促進政策は, 経済全体の雇用者所得を押し上げる効果がある。より重要なのは, 農家の所得向上につ ながる可能性を持つことである。

キーワード

バイオエタノール, キャッサバ栽培, サトウキビ栽培, 温室効果ガス, 雇用者所得

Graduate School of Business and Commerce, Keio University

2-15-45, Mita, Minato-ku, Tokyo 108-8345, Japan

$\dagger \quad$ Corresponding author 


\section{1. はじめに}

タイでは，サトウキビから砂糖を製造する過程で生じるモ ラセス (廃糖蜜) ならびにキャッサバを原材料としてバイオエ タノールが製造され，それをガソリンと混合したガソホール が自動車用然料として広く利用されている。タイ政府は，ガ ソホール普及促進に向けて, 2003 年より様々な政策を実施し てきた。

ガソホール推進政策の中心は，価格政策である。夕イ政 府は，ガソホールに対してガソリンに課される税金等を減免 することで，ガソリンよりも価格が低くなるように価格調整を 行ってきた。当初, ガソホールによる燃料代替は順調に進み, ガソリン自動車用燃料の市場におけるガソホールの比率は, 2005 年に全体の 9\% (体積比率)，2009 年には 59\%（体積 比率）となった。その後, 原料作物価格の高騰などの影響 により，2012 年頃までガソホール消費量が伸び悩んだ。そ のため，2013 年1月，タイ政府はそれまで度々延期されてき たレギュラーガソリンの販売停止に踏み切った。これを受け てガソホールの消費量は急増し，2013 年は対前年比 $68 \%$ の 増加を記録した。レギュラーガソリンは，ほぼガソホールへ と切り替わり, 2014 年にはガソリン自動車用燃料の市場の 93\%（体積比率）をガソホールが占めるに至った。

価格調整以外の政策としては，エタノール生産業者に対す る税制上の優遇措置の付与があげられる。また，ガソホー ルを販売するガソリンスタンドの拡充，ガソホール対応車の 普及などインフラの整備にも力を入れている。なお， 2016 年 から新たな自動車物品税が導入されることが決定しており, 税率区分が従来の排気量基準から $\mathrm{CO}_{2}$ 排出量基準へ変更さ れるため，ガソホール普及にはさらなる追い風となる可能性 がある。

一連のガソホール推進政策による効果は, エネルギー, 環境，農業，地域経済など異なる分野において期待されて きた。具体的には，ガソリン消費量の削減による原油輸入 量の低減や，エ夕ノール原料作物の栽培農家の所得向上, 農村部の発展などである。また，エ夕ノールを含む再生可 能エネルギー拡大政策の目的には，温室効果ガスの排出削 減が揭げられている。これまで，エタノール生産にともなう GHG 排出量やその経済性については，プラントレベルでの LCA による評価が行われてきた ${ }^{1) ~-5) 。 し か し ， ~ カ ゙ ソ ホ ー ル ~}$ の生産がおよぼす影響，輸送という生産活動における燃料 代替の効果は，産業連関を通じて国全体に波及する。その ため，プラントレベルだけでなく，経済全体で評価する必要 がある。

本研究の目的は, タイにおけるバイオエタノール政策が国 全体にもたらした影響を多角的に明らかにすることである。 自動車用燃料としてのバイオエタノールの利用は, 農業, エ ネルギー産業，輸送業など様々な産業活動に影響を与えるた め，産業間のつながりを適切にとらえる必要がある。また， GHG 排出量の削減や所得の増加など，異なる観点からの分 析を，整合的に行うフレームワークが求められる。これら二 つの点を踏まえ, 本研究では, 夕イの産業連関表をガソホー
ル政策の分析に適したものに改良し，それを用いて影響評 価を行い，今後の政策の方向性について検討する。評価に は，急速に代替が進んだ 2014 年の現状を反映させる。ガソ ホール導入の影響をマクロの視点から評価した研究に関して は, 将来についてのシミュレーションを行った分析は散見さ れるものの ${ }^{6)}{ }^{7)}$ ，現実を反映させた事後的な評価は行われて いない。

\section{2. 分析の方法}

\section{1 評価の前提}

\section{1 .1 ガソホールの分類と消費の趨勢}

タイで使用されているガソホールには，以下の 4 種類 が存在する。オクタン価 91 のレギュラーガソリン（以下， ULG91）にバイオエタノールを 10\%混合したE10（91），才 クタン価 95 のハイオクガソリン（以下, ULG95）にバイオエタ ノールを $10 \%$ 混合したE10（95），ULG95に20\%，85\%の エタノールを混合した E20, E85 である。E10（91）, E10（95） は, 2005 年頃から本格的な普及段階に入った。当初, ULG95 の販売を停止し，全量 E10（95）で代替する方針 が打ち出されていたため，E10（95）を中心として消費が 拡大した。しかし，その政策は実施に至らず，前述の通り， ULG91 が販売終了となったため，2012 年にE10（95）と E10（91）の消費量が逆転した。2014 年の消費量は，ガソ リンが 56 万 kLであるのに対し，E10（91）が 334 万 kL, E10（95）が 303 万 kL である。一方，E20 と E85 の消費が 始まったのは, 2008 年からである。その後の増加率は小幅 であったが，2013 年から徐々に消費量が増加し，2014 年に は E20 が 96 万 $\mathrm{kL} ， \mathrm{E} 85$ が 14 万 $\mathrm{kL}$ 消費された。

\subsection{2 エタノール原料作物と生産状況}

タイに打けるエタノールの原料は，モラセス（廃糖蜜）と キャッサバであるが，エタノールの生産が開始されてから現 在まで, 主要原料はモラセスである。キャッサバ由来のエ夕 ノールは，モラセス由来エタノールよりも製造コストが高いこ と，モラセスと比較すると原料収集の点で不利なこと，害 虫被害や担保融資制度の影響によりキャッサバ価格が上昇 したことなどから，予定されたようには生産拡大が進んで来 なかった。ただし，ここ数年で新たに稼働した，あるいは， 今後稼働する予定のエタノールプラントは，全てキャッサバ を原料としている。既に，モラセスの供給の大幅増加は見 込めないことから，キャッサバの利用が徐々に増加する可能 性は高い。また，ここ数年は，ケーンジュース（サトウキビ搾 り汁）の利用も増加傾向にある。

2015 年 2 月時点で稼働しているエタノールプラントは，モ ラセスを原料とするものが 11 ケ所（生産能力 221 万 L/ day)，キャッサバを原料とするプラントが 6 ケ所（同 128 万 L/day)，モラセスとキャッサバの両方を用いるプラントが4 ケ 所（同 70 万 L/day）である。将来的に稼働が予定されてい る 4 ケ所のキャッサバエタノールプラントの生産能力は, 137 万 L/dayである。 


\section{2 バイオエタノール部門拡張産業連関表の作成}

バイオエタノール部門拡張産業連関表を，現在公表されて いる夕イの最新の産業連関表である「2005 年産業連関表」8) をベースとして作成した。既存の産業連関表（以下, IO 表) には，バイオエタノール，ガソホール製造に関する独立部門 は存在しない。そこで, これらの部門を新たに作成し，既存 の IO 表に組み込むことで，バイオエタノール導入効果の分析 を可能にする拡張 IO 表を開発した。

新設した部門は，バイオエタノール部門とガソホール部門 である。バイオエタノール部門は，モラセスエタノール部門と キャッサバエタノール部門の 2 部門を作成した。ガソホール 部門は, E10（91），E10（95），E20，E85の４部門を作成 した。その結果, 拡張 IO 表は, 既存の 180 行× 180 列の 表に新たな 6 部門を加えた 186 行× 186 列の表となった。な お, サトウキビ生産, キャッサバ生産, 製糖業, キャッサバ 加工業については独立部門が存在するため, 既存の部門を 利用することができる。

\section{2 .1 モデルプラントの想定}

Table 1 にバイオエタノール部門作成の対象としたモデル プラントの概要を示す。モラセスエタノール部門のモデルプ ラントの原料はモラセスのみで, ケーンジュースは用いないと した。キャッサバエタノール部門のモデルプラントは, キャッ サバチップを原料とし，生のキャッサバは使用しないとした。 生産規模は $150 \mathrm{kl} / \mathrm{day}$, 年間稼動日数は 330 日で共通とした。 エタノールプラントは, 立地の違いから, 製糖工場併設型, キャッサバスターチ工場併設型, 独立型の3つに分類する ことができる。モラセスエタノール部門のモデルプラントは, 最も一般的な製糖工場併設型とした。製糖工場では，製糖 プロセスで発生するバガスを燃料として蒸気生産と自家発電 を行っている。製糖工場併設型のプラントでは，製糖工場か らバガスを用いて発電した電力を購入して必要電力をまかな うとした。蒸気については, 蒸留廃液から回収したバイオガ スを用いて生産する。モラセス由来のエタノールの場合，エ タノール $1 \mathrm{kl}$ あたり $313.1 \mathrm{Nm}^{3}-\mathrm{CH}_{4}$ のバイオガスが発生する。

キャッサバエタノール部門のモデルプラントは, 最も一般 的である独立型とした。独立型の場合, 製造プロセスに必 要な電力はグリッドから購入する。蒸気生産は, モラセスエ タノールと同様にバイオガスを用いて行うが, 原料がキャッサ バの場合, バイオガス発生量はモラセスよりも少ない。キャッ サバ由来エタノール $1 \mathrm{kl}$ あたりのバイオガス発生は 148.6 $\mathrm{Nm}^{3}-\mathrm{CH}_{4}$ であり, バイオガスだけでは必要な蒸気の全量を生 産できないため, 補助燃料として石炭を用いる。必要となる
石炭の量は，エタノール $1 \mathrm{kl}$ あたり 0.15 ton である。

\section{2 .2 バイオエタノール部門の作成}

バイオエタノール部門の投入額ベクトル（列部門）の作成 には，エタノール製造コストの内訳データが必要となる。本 研究では, タイに拈て, 8ヶ所のエタノールプラント, 農業. エネルギー・経済分野の専門家, 代替エネルギー開発・省 エネ局 (Department of Alternative Energy Development and Efficiency: DEDE）に対してヒアリングを実施し，コストデー 夕および情報を収集した。製造コストは, 原料費, 消耗品費 (薬品等), 燃料費, 電力·水道料金, 人件費, 保守 - 修繕 費, 保険料, 減価償却費, 諸費から構成される。可能な限 り平均的なコスト構造を推計するため, 複数のプラントのデー 夕を用いるとともに, DEDEによる文献9)の值も参考にして 各項目の金額を決定した。これらのコスト総額と, ヒアリン グで得た平均利潤額との合計金額を生産額とした。各コスト 項目は，I/O 表の部門定義にしたがい, 該当する部門に計 上した。なお，諸費は一般管理費に相当するものと仮定し， 既存の蒸留酒部門の投入額比率を用いて金額を按分し, 関 連部門に計上した。

産出額ベクトル（行部門）は, エタノールの販路構成デー 夕により作成される。本推計では, 生産したエタノールはガ ソホール製造のみに使用され，かつ，全て国内で消費される と想定し，全額，新設したガソホール部門に産出するとした。

\subsection{3 ガソホール部門の作成}

ガソホール部門は, バイオエタノールとガソリンの混合, 給油所までのガソホール輸送および販売を行う部門であると 定義する。投入額ベクトルの作成では，原料費（バイオエ夕 ノール，ガソリン）の他, 混合および販売に係る人件費と輸 送費, 営業余剩, 税金を計上した。原料費以外のコストは, エネルギー政策計画局 (Energy Policy and Planning Office: EPPO）により公表される石油製品価格構成デー夕 10)を用い て求めた。人件費と輸送費, 営業余剰は, 石油製品価格構 成データから得られる精製・流通マージンを, 既存の石油精 製部門の投入額比率で按分して算出した。

IO 表における各部門は, それぞれの生産活動の中で必要 に応じて自家輸送を行うため, ガソリンやガソホールは, 道 路貨物輸送部門以外の部門においても中間投入財として消 費されている哪注1)。よって，ガソホール部門の産出額ベクト ルを作成するためには, 道路貨物輸送部門を含む全ての部 門を対象に，ガソホールの販路構成を推計する必要がある。 推計においては，i）ガソリンとガソホールの代替比率は全部 門共通である, ii）ガソホールの販路構成はガソリンの販路

Table 1 Bioethanol production plants considered

\begin{tabular}{|c|c|c|c|c|c|c|}
\hline & Feedstock & Capacity & Operating days & Configuration & Electricity & Steam \\
\hline Molasses ethanol & Molasses & $150 \mathrm{~kL} /$ day & 330 days/year & co-location & bagasse & biogas \\
\hline Cassava ethanol & Cassava chip & 150 kL/day & 330 days/year & stand-alone & grid & biogas+coal \\
\hline
\end{tabular}

脚注 1）ただし，IO 表の部門定義では，道路貨物輸送部門にも 自家輸送が含まれると記載されている。 
構成と等しい，という2つの仮定を置いた。ただし，ガソリ ンが含まれる既存の石油精製部門には，ガソリン以外の石 油製品 (LPG，灯油，ディーゼル等）も含まれるため，石油 精製部門の販路構成をそのまま用いることはできない。

そこで，以下のようにガソリンのみの販路構成を推計した。 まず, タイの公式統計 ${ }^{11} 1$ 12) に 15 業種別に記載されている 12 種の石油製品消費量を，業種ごとに該当する IO 表の石油 精製部門の産出額比率を用いて按分し，ガソリン以外の石 油製品の販路構成を求めた。それを石油精製部門の産出額 から差し引くことで，ガソリンのみの販路構成を算出した。 ガソホール部門の行ベクトルは，この販路構成にガソホール 消費額を乗じることで作成される。

\section{2 .4 既存部門の投入係数の修正}

前述の通り，ガソリン，ガソホールは各内生部門でも消費 される。よって，ガソリンとガソホールが代替した場合，各 部門の投入構造が変化する。ガソリンは同等の熱量を有す るガソホールによって代替され，かつ，両者は単価も異なる ため，代替にともない中間投入額が変化する。ガソリン，ガ ソホールの中間投入額は，評価を行うケースにおける代替比 率に基づき算出したガソリン，ガソホールの消費量に，それ ぞれの単価を掛け合わせて求めた。その上で, 輸送用燃料 の転換による中間投入額の変化は付加価值で吸収され，各 部門の製品価格には転嫁されないと仮定し，代替後の投入 係数を求めた。

\subsubsection{GHG 排出原単位の推計}

新設部門を含む 186 部門について, $\mathrm{CO}_{2}$ 排出原単位を推 計した。エタノール (キャッサバ) 部門の $\mathrm{CO}_{2}$ 排出原単位は, 製造プロセスでの石炭投入量，石炭単価および石炭の $\mathrm{CO}_{2}$ 排出係数から $\mathrm{CO}_{2}$ 排出量を推計し, それを生産額で割るこ とで $\mathrm{CO}_{2}$ 排出原単位を求めた。ガソホール部門は，製造プ ロセスにおいて化石燃料の直接燃焼は行われないため, $\mathrm{CO}_{2}$ 排出原単位はゼロとなる。

新設部門以外の既存の 180 部門の $\mathrm{CO}_{2}$ 排出原単位は, 2000 年のタイ IO 表を対象として $\mathrm{CO}_{2}$ 排出原単位を推計した 文献 13) の方法に基づき， 2005 年の $\mathrm{CO}_{2}$ 排出原単位を新た に推計した。ただし，エタノール原料作物の栽培は評価に おいて重要であるため, サトウキビ部門，キャッサバ部門の 2 部門については，化石燃料消費にともなう $\mathrm{CO}_{2}$ 排出量た けでなく，栽培時に発生する $\mathrm{N}_{2} \mathrm{O}, \mathrm{CH}_{4}$ も加味した原単位を 作成した。施肥にともなう $\mathrm{N}_{2} \mathrm{O}$ 発生量は, ヒアリングで収集 したそれぞれの作物の平均施肥量と NPK 比から推計した。 サトウキビ収穫時の火入れにともなう $\mathrm{N}_{2} \mathrm{O}, \mathrm{CH}_{4}$ 排出量は, 2005 年の火入れ率データ 14) を用いて, 文献 ${ }^{15)}$ の方法に基 づき推計した。

なお，ガソホールによりガソリンが代替された場合，内生 部門でガソリンを消費する全ての部門の $\mathrm{CO}_{2}$ 排出原単位が 変化する。よって，評価を行うケースごとに $\mathrm{CO}_{2}$ 原単位を推 計する必要がある。

\section{3 評価ケースと評価指標の設定}

\subsection{1 評価ケースの設定}

本研究では, バイオエタノール導入効果の評価を行うため,

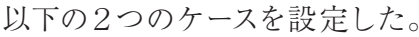

i) ケース $1: 2005$ 年ケース

2005 年のガソリン， ガソホール消費量の実績值ケースで ある。エネルギー事業局 (Department of Energy Business: DOEB）のデータ 16) から，2005 年のガソリン，ガソホール消 費量を求めた (Table 2)。Table 2 に示すと抢り，2005 年に は既にE10 (95) が導入され, ULG95を代替している。E10 (91) の導入量はごく少量であり，E20 と E 85 はまだ導入されてい ない。また， 2005 年時点では，キャッサバエタノールは生産 されておらず, エタノール生産は全量, モラセスを原料として 行われている。

ii) ケース $2: 2014$ 年ケース

2005 年時点のガソリン, ガソホール消費量に, 2014 年時 点のガソリン，ガソホール消費構成を当てはめた場合を想 定したケースである。2005 年の消費量実績值から満たすべ き熱量を算出し，それに熱量換算した場合の 2014 年のガ ソリン，ガソホール消費構成を掛け合わせて消費量を求めた (Table 2)。ULG91 は E10（91）に, ULG95 は E10（95）, E20, E85 によって代替される。熱量換算は, 文献 ${ }^{4}$ に基づき, ガソリンの低位発熱量を $31.8 \mathrm{MJ} / \mathrm{L}$ ，エタノールの低位発熱 量を $20.5 \mathrm{MJ} / \mathrm{L}$ として行った。

2014 年には，モラセス，キャッサバともに原料として使用 されている。DEDEへのヒアリングデータをもとに, 2014 年 の燃料用エ夕ノール生産に占める各原料の割合を，モラセス $72 \%$ ，キャッサバ $28 \%$ と設定した。モラセス，キャッサバの 使用割合の変化は，ガソホール部門の投入額ベクトルに反 映される。

\subsection{2 ガソホール価格構成の設定}

E20 と E 85 は, 2005 年時点ではまだ導入されていないため, 部門作成のための基礎データである石油製品価格構成デー タが存在しない。そこで, 本推計では, E10（95）の価格 構成をもとに，E20，E85の価格構成を決定した。その結果 をTable 3 に示す。精製・流通マージン，および，製品価格 に上乗せされる物品税，市町村税，石油基金，環境基金の 金額は，E10（95）と同じであると仮定している。なお，工 タノール参照価格の算定方法が 2005 年 9 月にコスト積上げ 法へと変更され，より実態が反映される価格が設定されるよ

Table 2 Consumption of gasoline and gasohol in two cases

\begin{tabular}{l|rr}
\hline & \multicolumn{1}{|c}{ Casel (2005) } & Case2 (2014) \\
& {$[1000 \mathrm{~kL} /$ year $]$} & {$[1000 \mathrm{~kL} /$ year $]$} \\
\hline ULG 91 & 4,333 & 76 \\
ULG 95 & 2,240 & 309 \\
E10 (91) & 29 & 4,444 \\
E10 (95) & 646 & 1,696 \\
E20 & 0 & 833 \\
E85 & 0 & 207 \\
\hline
\end{tabular}


Table 3 Price structure of gasohol

\begin{tabular}{|c|c|c|c|c|c|c|}
\hline & \multicolumn{2}{|c|}{ Casel (2005) } & \multicolumn{4}{|c|}{ Case2 (2014) } \\
\hline & $\begin{array}{c}\text { E10(91) } \\
{[\text { Bath/L] }}\end{array}$ & $\begin{array}{c}\text { E10(95) } \\
\text { [Baht/L] }\end{array}$ & $\begin{array}{c}\text { E10(91) } \\
{[\text { Baht/L] }}\end{array}$ & $\begin{array}{c}\text { E10(95) } \\
\text { [Baht/L] }\end{array}$ & $\begin{array}{c}\text { E20 } \\
{[\mathrm{Baht} / \mathrm{L}]}\end{array}$ & $\begin{array}{c}\text { E85 } \\
{[\text { Baht/L] }}\end{array}$ \\
\hline Ex-refinery price & 17.06 & 17.51 & 17.09 & 17.54 & 17.72 & 18.90 \\
\hline Excise tax & 3.32 & 3.32 & 3.32 & 3.32 & 3.32 & 3.32 \\
\hline Municipal Tax & 0.33 & 0.33 & 0.33 & 0.33 & 0.33 & 0.33 \\
\hline Oil Fund & 0.37 & 0.37 & 0.37 & 0.37 & 0.37 & 0.37 \\
\hline Consevation Fund & 0.04 & 0.04 & 0.04 & 0.04 & 0.04 & 0.04 \\
\hline VAT (7\%) & 1.48 & 1.51 & 1.48 & 1.51 & 1.52 & 1.61 \\
\hline Marketing margin & 1.52 & 1.52 & 1.52 & 1.52 & 1.52 & 1.52 \\
\hline VAT (7\%) & 0.11 & 0.11 & 0.11 & 0.11 & 0.11 & 0.11 \\
\hline Retaile price & 24.21 & 24.69 & 24.24 & 24.73 & 24.92 & 26.18 \\
\hline
\end{tabular}

Table 4 Final demand of gasohol in two cases

\begin{tabular}{|c|c|c|}
\hline & $\begin{array}{c}\text { Casel (2005) } \\
\text { [1000Baht] }\end{array}$ & $\begin{array}{c}\text { Case2 (2014) } \\
\text { [1000Baht] }\end{array}$ \\
\hline E10 (91) & 265,511 & $40,742,809$ \\
\hline E10 (95) & $6,032,623$ & $15,860,810$ \\
\hline E20 & 0 & $7,854,458$ \\
\hline E85 & 0 & $2,049,386$ \\
\hline
\end{tabular}

うになった。よって, 推計には 2005 年 9 月〜 12 月のデータ の平均值を用いた。

\subsection{3 最終需要の設定}

推計のための最終需要は, 以下のように設定した。

i）ガソリンとガソホールは，内生部門および最終需要部門 （民間消費支出，政府消費支出）で消費される。最終需 要部門のガソホール消費額は, ガソホール部門の行ベク トル作成において推計したガソホールの販路構成データ を用いて求めた。Table 4 に，2つのケースのガソホール 4 部門 (E10 (91)，E10（95），E20，E85）の最終需要 額を示す。なお，ガソリンの最終需要額は，石油精製部 門の最終需要額からガソホール 4 部門の最終需要額合計 を差し引くことで表される。

ii）バイオエタノールは全額, 中間投入されるため, バイオエ タノール部門の最終需要はゼロとなる。

iii）上記以外の部門には，2005 年の最終需要額をそのまま 与えた。

\subsection{4 評価指標の設定}

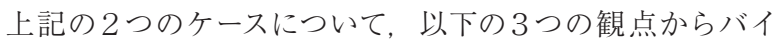
オエタノール導入効果の評価を行う。

1) 国内歩留まり率の変化:

エタノールは，モラセス，キャッサバというタイ国内の資源 を用いて生産される。輸送用燃料の転換に伴い, 各部門に おけるガソリンの投入量が減少し，エタノールを用いたガソ ホールの投入量が増加する。これにより，各部門の生産波 及効果の国内歩留まり率が変化すると予想される。第 $j$ 部門 の国内歩留り率 $\left(D_{j}\right)$ は, 第 $\mathrm{j}$ 部門による波及効果が国内に
とどまる比率を示す指標であり，式（1）によって算出される。

$$
D_{j}=\sum_{i=1}^{n} b_{i j} / \sum_{i=1}^{n} b_{i j}^{d}
$$

ただし， $b_{i j}$ は式 (2)により, $b_{i j}{ }_{i j}$ は式 (3)により求められる レオンチェフ逆行列 $\mathbf{B}, \mathbf{B}^{\mathrm{d}}$ の行列要素である。

$$
\begin{aligned}
& \mathbf{B}=(\mathbf{I}-\mathbf{A})^{-1} \\
& \mathbf{B}^{\mathbf{d}}=\left(\mathbf{I}-\mathbf{A}^{\mathbf{d}}\right)^{-1}
\end{aligned}
$$

ここで, I は単位行列, $\mathbf{A}$ は輸入品が夕イ国内で生産されてい ると仮定した場合の投入係数行列, $\mathbf{A}^{\mathrm{d}}$ は輸入表を用いて求 めた国産品に対する投入係数行列である。レオンチェフ逆行 列の $j$ 部門の列和は, 部門 $j に 1$ 単位の需要が生じたときに 全部門で誘発される波及効果の大きさを示す。

2) GHG 排出量の変化:

エタノールの導入が $\mathrm{GHG}$ 排出量の削減に貢献しているか 否かを確認するとともに, 排出量をより少なくする方策につい て検討することを目的とし, GHG 排出量の変化を計測する。 各内生部門の $\mathrm{GHG}$ 排出量 $(\mathbf{E})$ は, 式 (4)により算出される。

$$
\mathbf{E}=\hat{\mathbf{e}}\left(\mathbf{I}-\mathbf{A}^{\mathrm{d}}\right)^{-1} \mathbf{F}
$$

ここで, $\hat{\mathbf{e}}$ : 各内生部門の直接 GHG 排出原単位の対角行列, $\mathbf{I}$ : 単位行列, $\mathbf{A}^{\mathbf{d}}$ : 国産品投入係数行列, $\mathbf{F}$ : 最終需要ベクト ルを示す。 $\hat{\mathbf{e}}, \mathbf{A}^{\mathbf{d}}, \mathbf{F}$ はケースにより異なる。また, 最終需要 部門からの燃料燃焼に伴う GHG 排出量は, 各燃料の消費 量と GHG 排出係数を乗じることで求めている。

3) 雇用者所得の変化:

エタノール導入の重要な目的の一つに農村部の所得向上が ある。農村部と都市部の所得格差は深刻な問題であり, 工 タノールの導入が所得の形成にどのような影響を与えるかを 分析することは極めて重要である。そこで，3つ目の評価指 標として, 雇用者所得の変化を計測する。各内生部門の雇 用者所得 $(\mathbf{W})$ は, GHG 排出量と同様に以下の式で求める ことができる。

$$
\mathbf{W}=\hat{\mathbf{w}}\left(\mathbf{I}-\mathbf{A}^{\mathbf{d}}\right)^{-1} \mathbf{F}
$$

ただし, $\hat{\mathbf{w}}$ は雇用者所得率であり, 粗付加価值部門の中の雇 用者所得額を国内生産額で除することで求められる。 


\section{3. 結果と考察}

\section{1 国内歩留まり率の変化}

Fig. 1 に国内歩留り率の推計結果を示す。横軸は, IO 表 の 180 部門を，縦軸は，2つのケース間における歩留り率の 変化率を示す。Fig. 1 が示すように, 輸送用燃料の転換によ り，167 部門で国内歩留り率が上昇するという結果が得られ た。これは，石油精製部門の国内歩留り率が $43 \%$ あるの に対し，ガソホール（E10）部門の国内歩留り率が 63\%であ ることから，ガソホールへの転換にともない各部門の中間投 入における原材料の輸入品比率が下がり，それにより国外 への波及効果の流出が減ったためであると考えられる。この 結果から，エタノールの導入は，総じて国内歩留まり率を高 める効果を持つことが示唆された。

ただし，ガソホール（E10）部門の歩留り率は，石油精製 部門のそれよりは高いものの，ガソホール（E10）のエタノー ル混合比率は 1 割にすぎず，9割分はガソリンであるため, ガソホール (E10) への転換による効果は限定的である。ガ ソホール（E85）部門の歩留り率は 86\%であることから，工 タノール混合比率を高めることができれば，国内歩留まり率 がさらに高まると見込まれる。そのためには，原料作物の供 給，および，E85を取り扱うスタンドの増加や対応車両の普 及などのインフラ整備が鍵となる。

\subsection{GHG 排出量の変化}

Table 5 に GHG 排出量の推計結果を示す。輸送用燃料を ガソリンからガソホールへ切り替えることによって, GHG 排 出量はネットで 109 万 t- $\mathrm{CO}_{2}$ eq./year 減少すると算定された。
ガソホールへの燃料転換により, 輸送時のガソリン, ガソホー ル燃焼にともなう排出量が減少する。具体的には，内生 部門と最終需要部門でそれぞれ 78.5 万, 47.8 万 t- $\mathrm{CO}_{2}$ eq. $/$ year 減少し，合計で 126 万 t- $\mathrm{CO}_{2}$ eq. /yearの GHG 排出量が 削減される。

一方，ガソホールの生産にともなう排出量は，ガソリンの それよりも大きいため，生産プロセスにおける GHG 排出量は 増加する。内生部門で消費されるガソリンが減り，ガソホー ルが増えることによって，ガソリンとガソホールの生産に伴 い排出される $\mathrm{GHG}$ 量は 11.2 万 $\mathrm{t}-\mathrm{CO}_{2} \mathrm{eq}$. / year の増加となる。 最終需要部門でも同様に消費されるガソホール量が増える ため，ガソリン，ガソホールの生産に伴う GHG 排出量は 6.5 万 t- $\mathrm{CO}_{2}$ eq. / year 増加する。生産プロセスにおける $\mathrm{GHG}$ 排 出量の増加は, 産業部門と最終需要部門を合わせて 17.7 万 t- $\mathrm{CO}_{2}$ eq. /year となった。以上の結果から， ガソリンから ガソホールへの転換は，GHG 排出量削減効果があるものの, ガソホールの生産にともなう排出量の増加は無視できない程 度に大きいことが示唆された。

Fig. 2 に生産プロセスにおける GHG 排出量の内訳を示す。 17.7 万 t- $\mathrm{CO}_{2}$ eq. /year の内訳は，増加分が 33.1 万 t- $\mathrm{CO}_{2}$ eq. / yearであるのに対し, 減少分が 15.4 万 t- $\mathrm{CO}_{2}$ eq. /year となっ ている。最も排出量の増加が大きい部門は発電部門であり, 増加分の約 $33 \%$ 占めている。発電部門についで排出量の 増加が大きい部門は，エタノール (キャッサバ) 部門, 原料 作物の栽培および加工部門である。サトウキビ・キャッサバ 部門の排出は, 施肥および収穫時の野焼きにともなう $\mathrm{N}_{2} \mathrm{O}$, $\mathrm{CH}_{4}$ の排出に起因する。

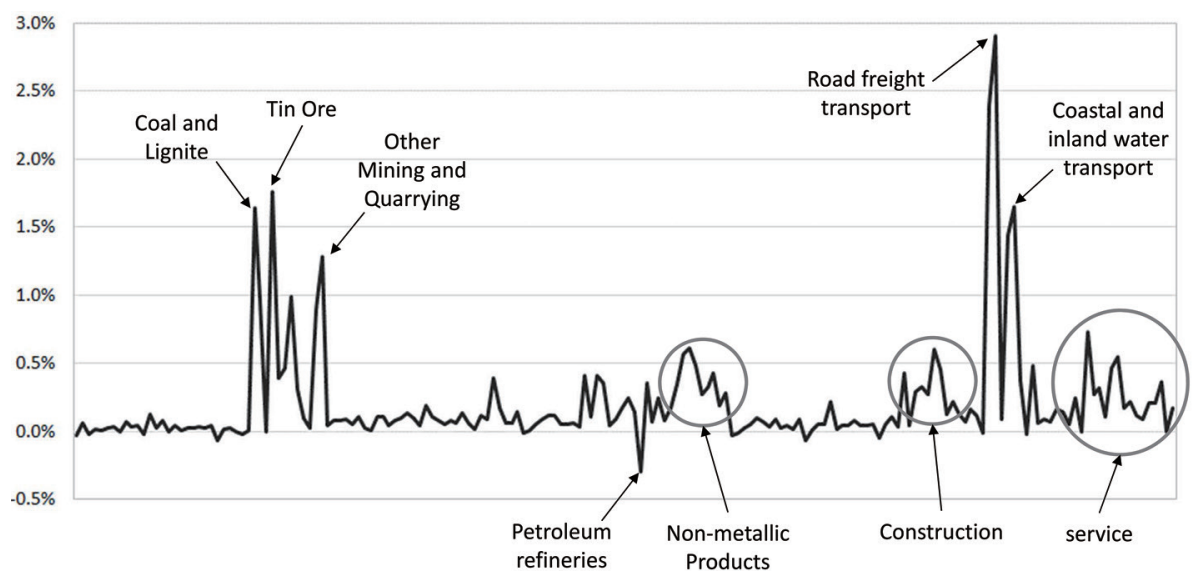

Fig. 1 Change in industrial linkage effects from base case

Table 5 Differences of GHG emissions between the two cases

\begin{tabular}{|c|c|c|c|c|}
\hline Processes & Demand sector & $\begin{array}{c}\text { Casel (2005) } \\
\text { [t-CO } \mathrm{CO}_{2} \text { eq./year] }\end{array}$ & $\begin{array}{c}\text { Case2 (2014) } \\
{\left[\mathrm{t}-\mathrm{CO}_{2} \text { eq./year] }\right.}\end{array}$ & $\begin{array}{c}\text { Difference } \\
\text { [t-CO } \mathrm{CO}_{2} \text { eq./year] }\end{array}$ \\
\hline \multirow[t]{2}{*}{ Fuel combustion } & Intermediate demand & $9,851,283$ & $9,065,812$ & $-785,471$ \\
\hline & Final demand & $5,992,576$ & $5,514,771$ & $-477,805$ \\
\hline \multirow[t]{2}{*}{ Fuel production } & Intermediate demand & $219,077,042$ & $219,188,944$ & 111,902 \\
\hline & Final demand & 943,720 & $1,008,318$ & 64,598 \\
\hline Total & & $235,864,622$ & $234,777,845$ & $-1,086,776$ \\
\hline
\end{tabular}




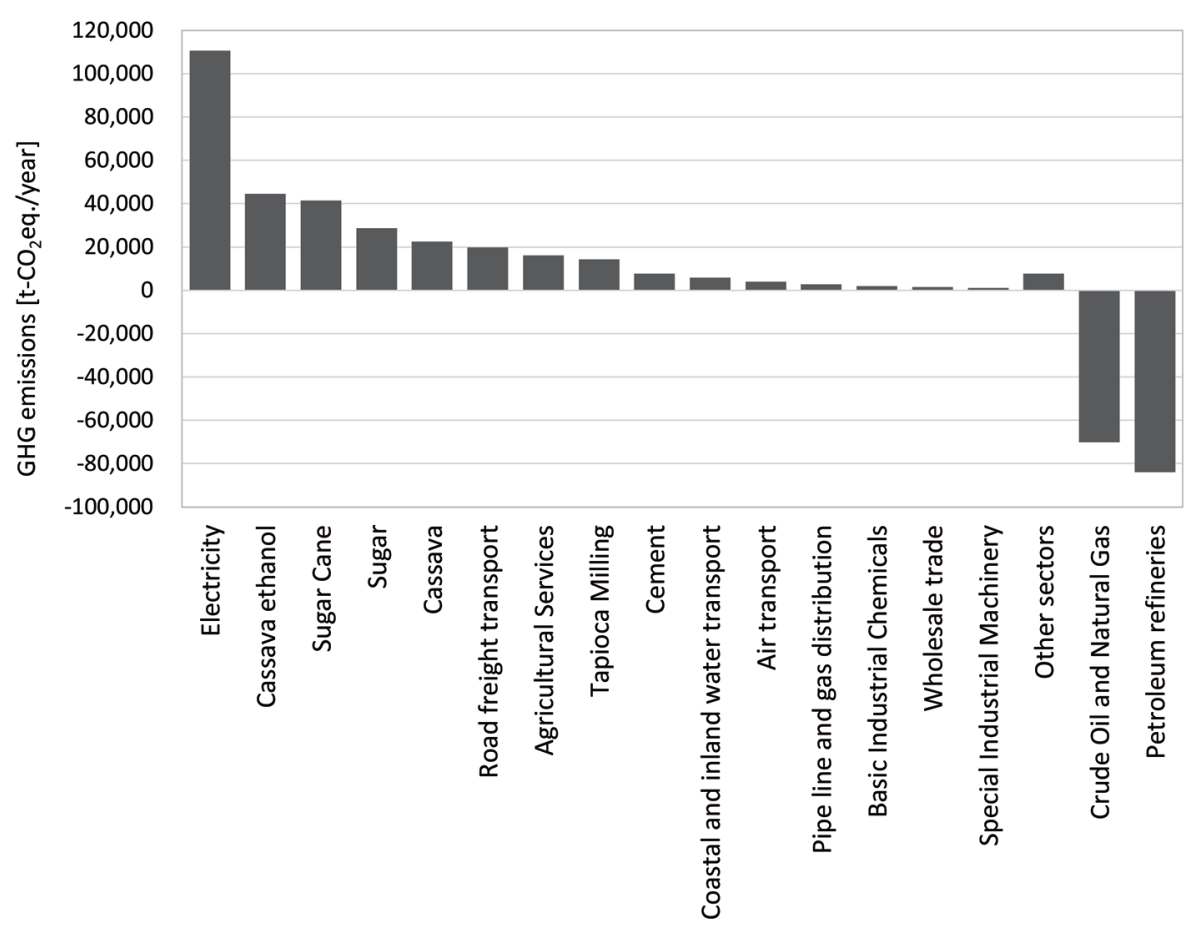

Fig. 2 Sectoral GHG emissions in production process

他方, 生産プロセスでの GHG 排出量の減少は, Fig. 2 に 示すとおり，ほぼ，原油・天然ガス部門と石油精製部門の生 産額減少に伴うものである。原油・天然ガス部門の GHG 排 出量の減少については, 以下の点に留意する必要がある。夕 イ IO 表の原油・天然ガス部門が対象とするアクティビティ は, 原油・天然ガスの探鉱 (地質調査, 試掘, 探掘), 開発 (生産井掘削, 施設建設), 生産である。よって, 同部門の GHG 排出量には, 原油・天然ガスの探鉱, 開発, 生産に伴 う排出が含まれる。タイでは, 原油・天然ガスの国産比率を 高めることを目的に, タイ石油開発公社(PTTEP) による原油・ 天然ガスの探鉱・開発事業が活発に行われている。輸送燃 料の転換によってガソリン需要が減少した場合, 原油・天然 ガスの生産量が減少する可能性はあるが，探鉱・開発に関 わる活動が抑制されるか否かは不明である。原油・天然ガ 又部門の生産額の減少に伴う GHG 排出量の減少は, これら の活動が一律に抑制された場合の值である点を踏まえておく 必要がある。

なお, 本推計は, 夕イ国内での GHG 排出量を対象として おり，国外での GHG 排出量は考慮していない。エ夕ノール生 産プロセスでは様々な薬品が必要となるが, 夕イはその大部 分を輸入に依存している。エタノール生産量が増加すれば, 当然のことながら薬品の投入量も増加し, その分, GHG 排 出量も増加する。しかし, その増加分は, 本推計での GHG 排出量には含まれていない。

\section{3 雇用者所得の変化}

Table 6 に雇用者所得の推計結果を示す。Table 6 は, 増 加額が大きい上位 15 部門と, 減少幅が大きい 2 部門を示し
ている。雇用者所得は, 燃料の代替により経済全体で $0.24 \%$ （61.5 億バーツ）増加すると算定された。原油・天然ガス部 門, 石油精製部門の生産活動がエタノール関連部門の生産 活動へとシフトした結果, 国内での取引が増えて誘発生産 額が増加し，それにともない雇用者所得も増加したと考えら れる。国内取引が増えたことの効果は, 卸売・小売部門や, 金融部門, 保険部門などサービス業の雇用者所得の増加に 表れている。

最も増加額が大きい部門はガソホール（E10（91））部門 であり, 増加額のうちの $28 \%$ を占める。ガソホール部門の活 動は, エタノールとガソリンの混合, および, ガソホールの 販売であり，石油会社が行うものである。したがって，ガソ ホール部門の雇用者所得の増加は, 石油精製部門内での所 得が, 既存の生産活動から新たな生産活動へとシフトしたも のと解釈することができる。

エタノール製造との連関が強い原料作物栽培における雇用 者所得に関しては，サトウキビ部門で 6.9 億バーツ，キャッ サバ部門で 6.5 億バーツの増加となっている。これらの部門 の所得増加は, 工業部門であるエタノール部門の所得増加よ りも大きい伸びを示している。また, 製糖部門やキャッサバ 加工部門の雇用者所得も, それぞれ, 7.8 億バーツ, 1.7 億バー ツ増加している。このような, 原料作物栽培部門, 原料作 物加工部門における雇用者所得の増加は, エタノール導入が 農家や農村部の所得向上という目的を満たす可能性があるこ とを示唆している。ただし, この数值は燃料転換にともない 必要となる原料作物が, 全て追加的に生産された場合を想 定したものであり，原料作物の供給制約を考慮していない点 に留意する必要がある。 
Table 6 Differences of employee income between the two cases

\begin{tabular}{l|rrr}
\hline \multicolumn{1}{c}{ Sectors } & \multicolumn{1}{c}{$\begin{array}{c}\text { Casel (2005) } \\
\text { [1000 Baht/year] }\end{array}$} & $\begin{array}{c}\text { Case2 (2014) } \\
{[1000 \text { Baht/year] }}\end{array}$ & $\begin{array}{c}\text { Difference } \\
\text { [1000 Baht/year] }\end{array}$ \\
\hline Gasohol (E10(91)) & $13,334,030,401$ \\
Sugar & $7,731,694$ & $2,043,735$ & 778,705 \\
Sugar Cane & $6,867,180$ & $8,510,399$ & 687,850 \\
Cassava & $6,843,464$ & $7,555,030$ & 647,364 \\
Molasses ethanol & 65,711 & $7,490,828$ & 603,499 \\
Gasohol (E10(95)) & 297,030 & 669,210 & 483,017 \\
Gasohol (E20) & 0 & 780,047 & 383,321 \\
Wholesale trade & $259,367,139$ & 275,945 \\
Cassava ethanol & 0 & 383,321 & 241,171 \\
Electricity & $102,291,113$ & 188,396 \\
Tapioca Milling & $1,576,542$ & $259,643,084$ & 173,269 \\
Banking service & $86,016,655$ & 241,171 & 154,952 \\
Gasohol (E85) & 0 & $102,479,510$ & 95,260 \\
Retail trade & $193,399,673$ & $1,749,811$ & 88,716 \\
Water work and supply & $9,056,003$ & $86,171,608$ & 63,886 \\
Petroleum refineries & $8,081,259$ & 95,260 & $-814,461$ \\
Crude Oil and Natural Gas & $40,444,264$ & $193,488,389$ & $-317,746$ \\
Other sectors & $1,867,190,983$ & $9,119,888$ & 384,377 \\
\hline Total & $2,589,242,045$ & $7,266,797$ & $6,147,921$ \\
\hline
\end{tabular}

\section{4. おわりに}

本研究では, エタノールの導入効果を評価するための IO 表を作成するとともに，国内歩留り率の変化，GHG 排出量 の変化, 雇用者所得の変化という3つの観点から推計を行っ た。その結果，以下の点が明らかになった。

・国内資源を活用したエタノールの導入は, 国内歩留り率を 高めるという観点からは意味を持つことが示唆された。さ らなる効果を得るためには, エタノールの混合比率を高め ることが有効である。

・エタノールによる燃料代替は，GHG 排出量の削減につなが ることが示唆された。ただし，ガソホールの生産の際の工 ネルギー消費による排出量の増加は，無視できないほどに 大きい。また，エ夕ノール生産に投入される薬品類の生産 による排出量の増加も考慮する必要がある。

・エタノール導入による取引構造の変化は, 大きくではない が, 国内の雇用者所得を全体的に押し上げることが示唆さ れた。また, 農家・農村の雇用者所得の向上に寄与する可 能性も持つことが明らかになった。

国内歩留り率，雇用者所得の面からは，原料作物である サトウキビ，キャッサバの生産が増加することの効果は大き い。また, 夕イ政府が目標とする 2021 年末までのエ夕ノール 消費量 (328.5 万 $\mathrm{kL} /$ 年) を実現するためには，原料作物 の生産増加は不可欠である。夕イでは, 農業生産増加のた めの耕地拡大は限界であると言われているため, 夕イ政府は 単収を向上させる取組みに尽力している。今後は, 単収を上 げるための技術の普及が極めて重要となる。

本研究の分析については，以下の 2 点に留意する必要があ る。

1）ガソホールがガソリンを代替することにより，各部門の内
生部門における投入額が変化する。本推計では, 各部門 は, 投入額の変化を付加価值で吸収すると仮定し, 生産 物の価格は変化させていない。しかし，長期的にみた場 合には，燃料転換による投入額の変化を受け，各部門が 生産物の価格を変化させる，あるいは，他の財の投入量 を変化させる可能性がある。

2) 今回の分析では，ガソホールの生産と消費による影響の みを対象としており，新規のプラント建設や， E20, E85 の消費拡大にともなうインフラ整備のための投資による影 響は評価に含めていない。低炭素社会への移行という側 面からは, インフラ整備による影響の把握は重要な研究 課題である。ガソホールの普及が拡大した場合，プラント 建設やインフラ整備のために，どの程度 $\mathrm{GHG}$ 排出量が発 生するか, どの程度雇用者所得が増加か, といった点も, 合わせて議論することが望まれる。

今後のエタノール生産拡大の鍵は, キャッサバの生産性向 上が握っている。しかし, 生産性の向上は容易でなく, 一 朝一夕には実現できないだろう。その場合, 現在, デンプン やチップ, ペレット生産に向けられているキャッサバが，エ夕 ノール生産に振り替えられる, すなわち, キャッサバ需要の 間で競合が起こる可能性がある。今後は，こうした状況を 反映した評価を行っていく必要がある。

\section{文 献: References}

1) Nguyen, T. L. T., Gheewala, S. H., Garivait, S., Energy Policy, 35, 4585-4596 (2007)

2) Nguyen, T. L. T., Gheewala S. H., Int J Life Cycle Asses, 13, 301-311 (2008)

3) Silalertruksa, T., Gheewala, S. H., Energy, 34, 1933-1946 
(2009)

4) Sorapipatana, C., Yoosin, S., Renew Sust Energ Rev, 15, 1343-1349 (2011)

5) Moriizumi, Y., Suksri, P., Hondo, H., Wake Y., J. Clean. Prod., 37, 326-334 (2012)

6) Silalertruksa, T., Gheewala, S. H., Hunecke, K., Fritsche, U. R., Biomass Bioenergy, 46, 409-418 (2012)

7) Wianwiwat, S., Asafu-Adjaye, J., Energy Policy, 55, 543555 (2013)

8) National Economic and Social Development Board (NESDB), Input-output table of Thailand 2005 (2005)

9) Department of Alternative Energy Development and Efficiency (DEDE), Life Cycle Assessment of Ethanol from Cassava and Sugar Cane, Final Report (2007)

10) Energy Policy and Planning Office (EPPO), Price structure of petroleum products in Bangkok, http:// www.eppo.go.th/petro/price/index.html
11) Department of Alternative Energy Development and Efficiency (DEDE), Thailand Energy Situation 2005 (2005)

12) Department of Alternative Energy Development and Efficiency (DEDE), Oil and Thailand 2005 (2005)

13) Moriizumi, Y., Hondo, H., J. Jpn. Soc. Energ. Resour., 29, 1-7(2008): 森泉由恵, 本藤祐樹, エネルギー・資源学会 論文誌, 29, 1-7 (2008)

14) Office of The Cane and Sugar Board (OCSB), Sugar production by sugar mill in 2004/2005 (2005)

15) Moriizumi, Y., Suksri, P., Hondo, H., Wake, Y., J. Jpn. Inst. Energy, 92(5), 491-502 (2013) : 森泉由恵, スクッスィー・ピ ヤワン, 本藤祐樹, 和気洋子, 日エネ誌,92(5), 491-502 (2013)

16) Department of Energy Business (DOEB), Petroleum Product Demand, http://www.doeb.go.th/info/data/ datadistribution/y_sale.xls 